DOI: $10.1515 /$ lpts-2017-0035

ELECTRONICS

\title{
EVALUATION OF SIGNAL REGENERATION IMPACT ON THE POWER EFFICIENCY OF LONG-HAUL DWDM SYSTEMS
}

\author{
D. Pavlovs, V. Bobrovs, M. Parfjonovs, A.Alsevska, G. Ivanovs \\ Institute of Telecommunications, Riga Technical University \\ 12 Azenes Str., Riga, LV-1048, LATVIA
}

\begin{abstract}
Due to potential economic benefits and expected environmental impact, the power consumption issue in wired networks has become a major challenge. Furthermore, continuously increasing global Internet traffic demands high spectral efficiency values. As a result, the relationship between spectral efficiency and energy consumption of telecommunication networks has become a popular topic of academic research over the past years, where a critical parameter is power efficiency.

The present research contains calculation results that can be used by optical network designers and operators as guidance for developing more power efficient communication networks if the planned system falls within the scope of this paper. The research results are presented as average aggregated traffic curves that provide more flexible data for the systems with different spectrum availability. Further investigations could be needed in order to evaluate the parameters under consideration taking into account particular spectral parameters, e.g., the entire C-band.
\end{abstract}

Keywords: differential phase shift keying, DWDM, energy efficiency, optical fibre networks, phase shift keying, power consumption, power efficiency, single-line rate, spectral efficiency, sub-band spacing, WDM networks

\section{INTRODUCTION}

The Information and Communication Technology (ICT) sector is experiencing continuously increasing global Internet traffic due to emergence and establishment of bandwidth-intensive applications (e.g., IPTV, YouTube, and cloud computing) [1]. Recent Cisco study has shown that the total IP traffic increases annually by an average of $23 \%$ for 2014-2019. The increased traffic raised the necessity of updating the existing transmission techniques and developing new ones in order to enchase spectral efficiency of systems.

In terms of wavelength division multiplexing (WDM) systems, the system capacity can be increased by either 1) channel-spacing reduction (increase of the transmitted channel number), or by 2 ) enhancing of channel capacities. The mentioned relation can be expressed by equation (1) [2]: 


$$
C=\sum_{i}^{M} C_{i k}
$$

where $\mathrm{i}$ - the index number of channel; $\mathrm{M}$ - the number of transmission channels; $\mathrm{C}_{\mathrm{ik}}$ - the speed of channel [bit/s].

However, higher spectral efficiency can result in the reduction of a transmission reach [3], [4]. Therefore in order to guarantee the required quality of transmission (QoT), an optical signal might require 3R (Re-amplification, Re-shaping, Retiming) regeneration procedure by means of optical-to-electrical-to-optical (OEO) conversion process, which in its turn requires the additional equipment in system nodes. As a result, the overall power consumption increases [5]. Thereby, it can be inferred that there is a trade-off among spectral efficiency, power consumption and transmission reach [1], [3], [4].

In the paper, the authors evaluate the impact of signal regeneration on power efficiency of a long-haul dense wavelength division multiplexing (DWDM) system by means of different channel spacing values, which is the most decisive factor for transmission reach of the system. This study aims at the single-line rate (SLR) solutions operating with $10 \mathrm{Gbps}, 40 \mathrm{Gbps}$ and $100 \mathrm{Gbps}$ transmission signals with the most frequently used modulation formats in modern high capacity networks - nonreturn-to-zero on-off-keying (NRZ-OOK), non-return-to-zero differential phaseshift keying (NRZ-DPSK) and dual polarisation quadrature PSK (DP-QPSK), respectively. The calculations of power consumption have been performed for 2960 $\mathrm{km}$ transmission distance in order to achieve more pronounced regeneration influence. The present research focuses on the WDM systems with forward error correction (FEC), which by virtue of an error controlling technique, allows successfully demodulating transmitted signals when the bit error rate (BER) does not exceed $10^{-3}$ threshold. This setup allows taking into account power consumption contributed by the redundant data required for FEC technology, which is commonly used in modern transmission systems [6].

\section{METHODOLOGY}

For this study, the evaluation of system power consumption was performed in two steps. At first, the relation between BER level and channel spacing was defined on the fixed fibre length using OptSim ${ }^{\mathrm{TM}}$ simulation software in order to define transmission reach and its relation with the channel spacing for each considered system setup [7], [8]. The assignment of central channel wavelength was based on the ITU-T recommendation G.694.1. The recommendation also provides the nominal central frequency granularity, which is equal to $6.25 \mathrm{GHz}$. Therefore, the cross-channel interval was increased by $6.25 \mathrm{GHz}$ at every simulation step with the purpose to find a frequency plan, whereby the BER level became lower than $10^{-3}$. Further, based on the obtained data from the above-mentioned simulations the power consumption evaluation model was developed using MATLAB features. In the calculation code, the amount of transmitted data was defined as a variable, which was used to calculate 
the required number of WDM components, which in conjunction with calculated transmission reach and chosen transmission distance determined the overall system power consumption. In this scenario, power consumption became a function of the transmitted data; therefore, calculation setup allowed evaluating power efficiency by dividing power consumption by the amount of transmitted data. The methodology was described in more detail in the previous papers [3] and [4].

For calculation purposes, the transmission distance was set for $2960 \mathrm{~km}$, which is comparable with the longest node of National Science Foundation Network (NSFNET) - the US network used in many studies, i.e., [9] and [10].

It was assumed that the total power consumption of WDM system could be calculated using equation (2):

$$
P_{W D M}=P_{R O A D M}+P_{T R A N S}+P_{W D M T E R M}+P_{O L A}+P_{3 R},
$$

where $\mathrm{P}_{\text {WDM }}$ - total power consumption of WDM system [W]; $\mathrm{P}_{\text {ROADM }}$ - power consumption of optical reconfigurable add/drop multiplexer [W]; $\mathrm{P}_{\text {TRANS }}$ - power consumption of transponder [W]; $\mathrm{P}_{\text {WDMTERM }}$ - power consumption of WDM terminal [W]; $\mathrm{P}_{\text {OLA }}$ - power consumption of optical line amplifier [W]; $\mathrm{P}_{3 \mathrm{R}}-3 \mathrm{R}$ (Re-amplification, Re-shaping, Re-timing) regenerator consumption [W].

Based on the provided datasheets and relevant studies [1], [4], [9], power consumption values of transponders and $3 \mathrm{R}$ regenerators are summarised in Table 1.

Table 1

Power Consumption [W] of Transponders and 3Rs

\begin{tabular}{|l|c|c|c|}
\hline Bit Rate (Gbps) & Modulation format & Consumer & Power (W) \\
\hline 10 & NRZ-OOK & TP/3R & 34.0 (Typ.) \\
\hline 40 & NRZ-DPSK & TP/3R & 85 (Max) \\
\hline 100 & DP-QPSK & TP/3R & 139 (Typ.) \\
\hline
\end{tabular}

It should be noted that the equipment under normal operational conditions does not consume the declared maximal power. Therefore, for calculations the nominal power consumption accounted for $75 \%$ of the specified maximal value.

Power consumption of ROADM multiplexers and WDM terminals, which are used for calculations, is demonstrated in Table 2 [1], [3], [9]. Power units of the optical line amplifier require 110W [3], [4], [9].

Table 2

ROADM and WDM Terminal Power Consumption [W]

\begin{tabular}{|l|c|c|}
\hline \multirow{2}{*}{ Device } & \multicolumn{2}{|c|}{ Power Consumption } \\
\cline { 2 - 3 } & $40 \mathrm{ch}$. realisation & 80 ch. realisation \\
\hline WDM terminal & 230 & 240 \\
ROAD multiplexer & 450 & 600 \\
\hline
\end{tabular}




\section{RESULTS AND DISCUSSION}

In this section, the authors present the simulation results that show the relation between the consumed power by means of power efficiency and 3Rs' power ratio and the amount of transmitted information, with the view of providing more flexible data for different system realisations, i.e., a different number of transponders due to distinctions in the available spectrum.

With the aim to evaluate power efficiency and regeneration impact at different spectral efficiency states, different channel spacing values were set, based on the recommendation ITU-T G.694.1. In this study, the power consumption values for each considered system realisation were evaluated using different cross-channel intervals on the ground that cross-channel interference is unique for each signal type, operating at the same frequency plan. Therefore it is not reasonable to analyse different systems using equal channel distribution if the purpose is to evaluate regeneration impact on the power efficiency and total power consumption. Lower frequency slot limit intended for analysis was chosen based on the highest spectral efficiency, which could be achieved guaranteeing the fulfilment of BER requirement. The upper limit was derived from conditions when the transmission reach attained its maximum, which meant that further increment of frequency slot would lead only to the minimisation of spectral efficiency without profitable impact on power consumption.

Since the present research considers different spectral efficiencies at different frequency slots, the transmission reach became a function of channel spacing. Relation between frequency slots, spectral efficiency (SE) and transmission reach is summarised in Table 3.

Table 3

Spectral Efficiency and System Reach at Different Channel Spacing Values

\begin{tabular}{|c|c|c|}
\hline Channel Spacing (GHz) & $\mathrm{SE}(\mathrm{bit} / \mathrm{Hz})$ & $\operatorname{Reach}(\mathrm{km})$ \\
\hline \multicolumn{3}{|c|}{10 Gbps NRZ-OOK } \\
\hline 12.50 & 0.80 & 160 \\
\hline 18.75 & 0.53 & 1680 \\
\hline 25.00 & 0.40 & 5700 \\
\hline 31.25 & 0.32 & 8720 \\
\hline \multicolumn{3}{|c|}{40 Gbps NRZ-DPSK } \\
\hline 50.00 & 0.80 & 160 \\
\hline 56.25 & 0.71 & 240 \\
\hline 62.50 & 0.64 & 560 \\
\hline 75.00 & 0.53 & 960 \\
\hline 87.50 & 0.46 & 1440 \\
\hline 100.00 & 0.40 & 2080 \\
\hline 112.50 & 0.36 & 2080 \\
\hline \multicolumn{3}{|c|}{100 Gbps DP-QPSK } \\
\hline 31.25 & 3.20 & 160 \\
\hline 37.50 & 2.67 & 400 \\
\hline 43.75 & 2.29 & 1040 \\
\hline 50.00 & 2.00 & 1360 \\
\hline
\end{tabular}


By defining transmission reach of the system and power consumption of WDM elements, the power efficiency and power ratio of $3 \mathrm{R}$ regenerators were evaluated. The results are shown in Figs. 1-6.

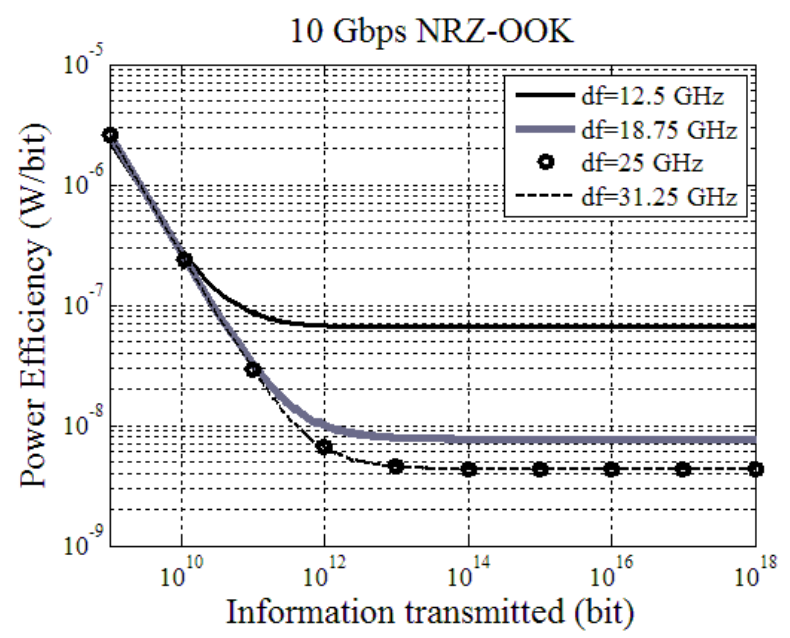

Fig.1. 10 Gbps NRZ-OOK power efficiency curve.

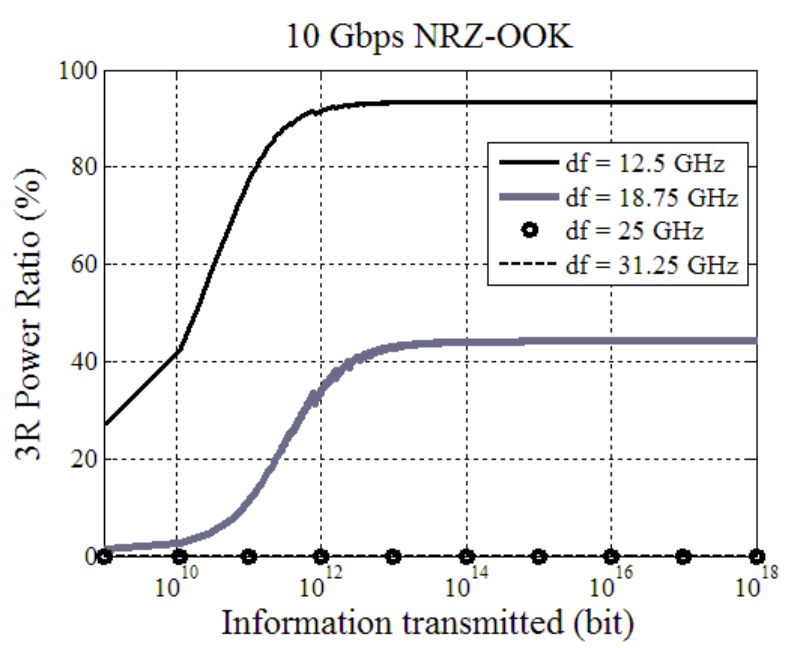

Fig.2. Power ratio curve of 10 Gbps NRZ-OOK 3R regenerators.

Figures 1-2 show the curves of the considered parameters for 10 Gbps NRZOOK system configuration from which it can be observed that when the total transmitted traffic reaches $\approx 10^{13}$ bits, power efficiency and $3 \mathrm{Rs}$ consumed power ratio stabilise, which allows making an assumption that parameters will not significantly change during system functioning and the obtained values can be used for system assessment and comparison. In spite of equal power efficiency, operation on the channel spacing values greater than $25 \mathrm{GHz}$ in the considered system is impractical in terms of spectral efficiency. Signal reach in those cases become greater than transmission span and signal regeneration is not required, thus power efficiency reaches minimal value in this instance $-4.30 \mathrm{nW} / \mathrm{bit}$. In the case of $12.5 \mathrm{GHz}$ and $18.75 \mathrm{GHz}$ 
frequency slots, PE values are 7.7 and $65.5 \mathrm{nW} / \mathrm{bit}$, respectively, which is a relatively abrupt leap of power consumption because for the transmission of a single bit the energy required is more than 15 times greater than using $25 \mathrm{GHz}$ frequency span. Thus, it can be concluded that if spectral efficiency should be increased, other signal types should be considered possibly better solutions from the power consumption point of view, because as it can be seen from Fig. 2, using $12.5 \mathrm{GHz}$ and $18.75 \mathrm{GHz}$ frequency slots between channels, $10 \mathrm{Gbps}$ signal regeneration requires $93.43 \%$ and $44.15 \%$ of total power consumed, respectively.

The second transmission signal type under consideration was 40 Gbps NRZDPSK. Figures 3-4 and Table 3 show spacing values of the considered channel. Since in this case transmission speed was $40 \mathrm{Gbps}$, signal spectrum was considerably wider in comparison with 10 Gbps NRZ-OOK spectra. This led to wider frequency slot requirement with the purpose to achieve the same quality of transmission (QoT) and thus the systems were evaluated using 50.0-100.0 GHz channel spacing. Six cross-channel intervals were analysed. The obtained results are provided in Table 4.

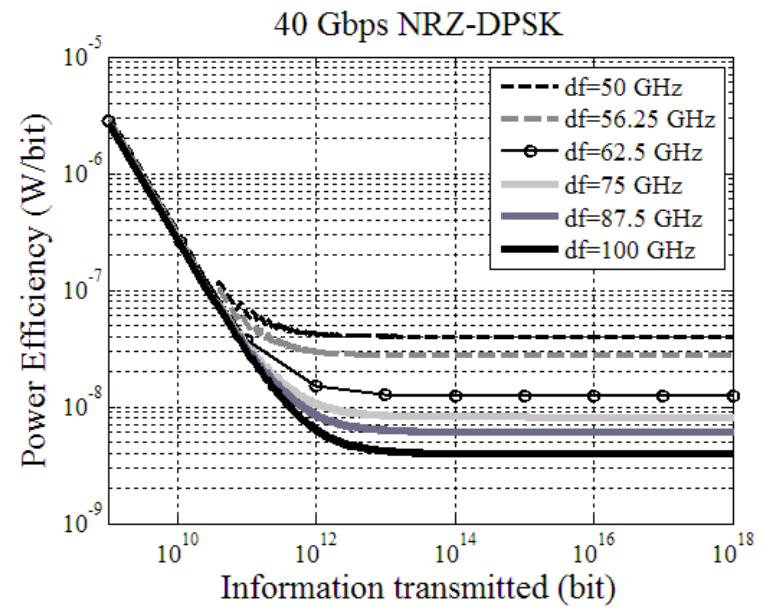

Fig.3. 40 Gbps NRZ-DPSK power efficiency curve.

40 Gbps NRZ-DPSK

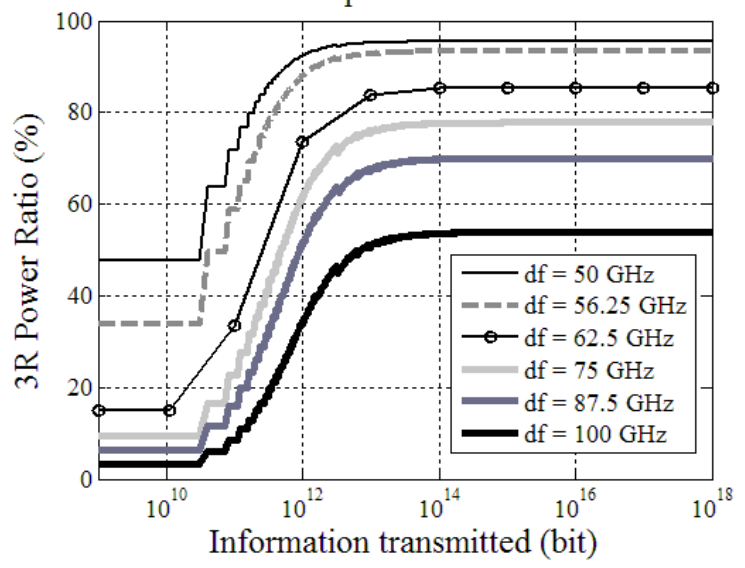

Fig. 4. Power ratio curve of 40 Gbps NRZ-DPSK 3R regenerators. 
Power Ratio Values of PE and 3Rs Operating at Different Frequency Slots

\begin{tabular}{|c|c|c|}
\hline Channel spacing $(\mathrm{GHz})$ & Power efficiency $(\mathrm{nW} / \mathrm{bit})$ & Power ratio of 3Rs $(\%)$ \\
\hline 50.00 & 40.07 & 95.46 \\
\hline 56.25 & 27.32 & 93.34 \\
\hline 62.50 & 12.44 & 85.38 \\
\hline 75.00 & 8.19 & 77.80 \\
\hline 87.50 & 6.07 & 70.03 \\
\hline 100.00 & 3.94 & 53.88 \\
\hline
\end{tabular}

On the ground of wider signal spectrum, by increment of frequency slot the power efficiency changed smoother than in the case of $10 \mathrm{Gbps}$. Therefore, increment of channel spacing for the amount of $12.5 \mathrm{GHz}$ had no such significant impact on the power efficiency of the system. In this case, the power ratio of $3 \mathrm{Rs}$ had more significant impact on total power consumption (more than $50 \%$ for each considered configuration) in comparison with NRZ-OOK because the transmission reach for this signal type was shorter. However, if 40 Gbps NRZ-DPSK operates with 100.0 $\mathrm{GHz}$ channel spacing, its power efficiency value is $3.94 \mathrm{nW} /$ bit, when the best scenario for $10 \mathrm{Gbps}$ NRZ-OOK is $4.3 \mathrm{nW} /$ bit operating with $25.0 \mathrm{GHz}$ frequency slot. This means that for the transmission of a single bit NRZ-OOK consumes by $\approx 8.37$ $\%$ more power than NRZ-DPSK having the same spectral efficiency.

A similar situation occurs in scenarios when cross-channel interference is most pronounced, operating with 12.5 and $50.0 \mathrm{GHz}$ channel spacing, respectively. In spite of the fact that power ratio of 3 Rs for OOK and DPSK is $93.43 \%$ and $95.46 \%$ respectively, power efficiency at $40 \mathrm{Gbps}$ system realisation is $40.07 \mathrm{nW} /$ bit against $65.5 \mathrm{nW} /$ bit in the case of $10 \mathrm{Gbps}$, which provides $\approx 63 \%$ difference in the required power for the transmission of a single bit.

The results of 100 Gbps DP-QPSK are summarised in Figs. 5-6.

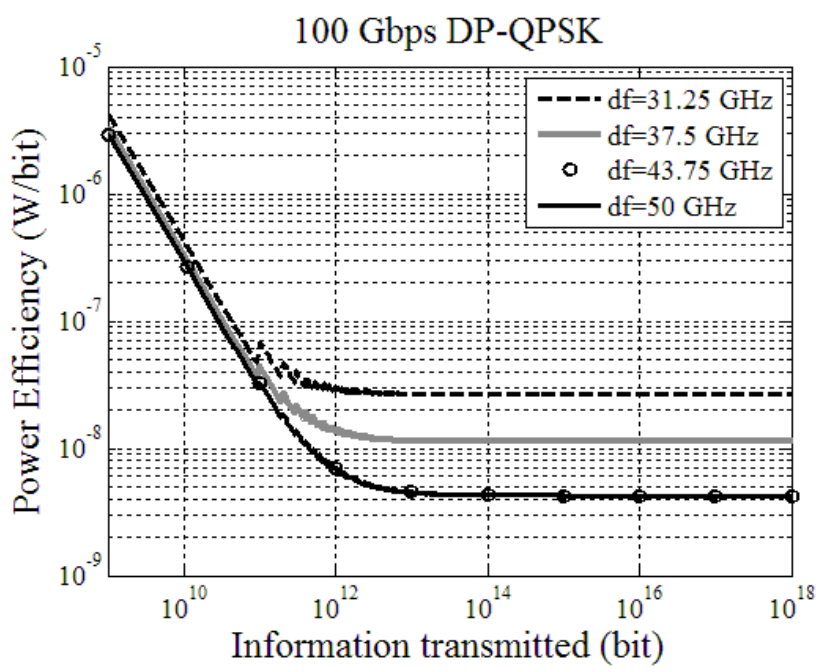

Fig. 5. 100 Gbps DP-QPSK power efficiency curve. 
100 Gbps DP-QPSK

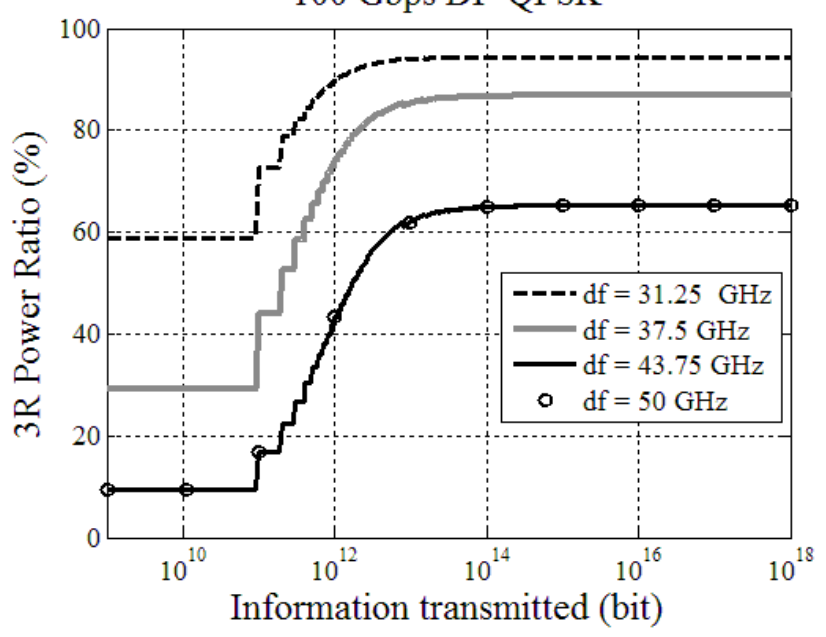

Fig. 6. 100 Gbps DP-QPSK 3R power ratio curve.

The obtained results show that minimal channel spacing to guarantee the required BER level is $31.25 \mathrm{GHz}$, which provides the power efficiency level equal to $26.50 \mathrm{nW} / \mathrm{bit}$. In virtue of a very efficient modulation format, spectral efficiency in this case is four times greater in comparison with both $10 \mathrm{Gbps}$ NRZ-OOK and 40 Gbps NRZ-DPSK and, furthermore, the considered transmission system is power efficient by $147 \%$ and $51 \%$ in comparison with NRZ-DPSK and NRZ-OOK, respectively. Other issues are practical and financial realisations of such signal transmittance, but this is out of scope of the present research.

Likewise in the previous instances, signal regeneration requires great amount of energy, even when cross-channel interference becomes minimal and only one regeneration action is required. In this case, $3 \mathrm{Rs}$ ratios are $65.26 \%, 86.80 \%$ and $94.42 \%$ operating at $43.75,37.5$ and $31.25 \mathrm{GHz}$ cross-channel intervals, respectively. Investigation has shown that using channel spacing values greater than 43.75 $\mathrm{GHz}$ for the considered system is unreasonable and does not have impact on the power consumption of the system. Using $43.75 \mathrm{GHz}$ cross-channel intervals, the power efficiency parameter of the system is $4.26 \mathrm{nW} / \mathrm{bit}$, which means that $40 \mathrm{Gbps}$ NRZ-DPSK transmission system, which uses $100 \mathrm{GHz}$ frequency spans, can be by $\approx$ $8.1 \%$ more power efficient than 100 Gbps DP-QPSK in the best scenario.

\section{CONCLUSIONS}

In the present research, the power efficiency of the three most popular signal modulation formats in the long-haul DWDM systems has been studied. The analytic model has been designed with the purpose that the error probability ratio for signal detection should be maintained lower than $10^{-3}$ at the receiving node at $2960 \mathrm{~km} \mathrm{P} 2 \mathrm{P}$ transmission distance. For this purpose by means of simulation using OptSim software, the transmission reach for each setup has been defined and using the obtained results the power consumption and efficiency of the system have been calculated. In addition, the impact of signal regeneration procedure has been examined on the total 
power consumption of the system for each simulation setup. The evaluation results have been presented as the functions of transmitted data volume operating at different channel spacing values, which allows adapting the results for WDM realisations with different available spectral bands.

The present research provides power efficiency values and the comparison for the DWDM setups, which operate with 10 Gbps NRZ-OOK, 40 Gbps NRZ-DPSK or $100 \mathrm{Gbps}$ DP-QPSK transmission signals, and gives an insight into the required power ratio intended for the considered signal regeneration. The results obtained within the framework of the research for the mentioned setups can provide useful guidance on designing a power-efficient DWDM long-haul system.

\section{REFERENCES}

1. Iyer, S., \& Singh, S.P. (2016). Spectral and power efficiency investigation in single- and multi-line-rate optical wavelength division multiplexed (WDM) networks. Photonics Network Communications. doi:10.1007/s11107-016-0618-3

2. Keiser, G. E. (1998). A review of WDM technology and applications. GTE Systems \& Technology, 21.

3. Pavlovs, D., Grinčišins, A., Bobrovs, V., Gavars, P., \& Ivanovs, G̣. (2016). Research of 10 Gbps NRZ-OOK signal spectral and energy efficiency. In Proc. ELECTRONICS 2016, 13 - 15 June 2016 (pp. 25-29). Lithuania: Kaunas University of Technology.

4. Pavlovs, D., \& Bobrovs, V. (2016). Relationship between spectral efficiency and energy efficiency in 10 Gbps NRZ-OOK, 40 Gbps NRZ-DPSK and 100 Gbps DP-QPSK WDM transmission systems. In Progress in Electromagnetic Research Symposium (PIERS 2016), 8-11 August 2016 (pp.1434-1438). Shanghai, China. doi:10.1109/ PIERS.2016.7734673

5. Haykin, S., \& Moher, M. (2007). An introduction to analog and digital communications. John Wiley \& Sons.

6. Morea, A., \& Spadaro, S., Rival, O., Perelló, J., Agraz, F., \& Verchere, D. (2011). Power Management of Optoelectronic Interfaces for Dynamic Optical Networks. DOI: 10.1364/ ECOC.2011.We.8.K.3

7. Chiani, M., Win, M. Z., \& Zanella, A. (2003). Error probability for optimum combining of M-ary PSK signals in the presence of interference and noise. IEEE Transactions On Communications, 51(11). doi: 10.1109/TCOMM.2003.819197

8. Meghdadi, V. (2008). BER calculation. Wireless Communications by Andrea Goldsmith.

9. Van Heddeghem, W., Idzikowski, F., Vereecken, W., Colle, D., Pickavet, M., \& Demeester, P. (2012). Power consumption modeling in optical multilayer networks. Photonics Network Communications, 24(2), 86-102. doi:10.1007/s11107-011-0370-7

10. Verbrugge, S., Colle, D., Demeester, P., Huelsermann, R., \& Jaeger, M. (2005). General availability model for multilayer transport networks. In Proc. 5th International Workshop on Design of Reliable Communication Networks, 16-19 October 2005. Lacco Ameno, Island of Ischa, Italy. DOI: 10.1109/DRCN.2005.1563848 


\section{SIGNĀLA REG̣ENERĀCIJAS IETEKMES NOVĒRTĒŠANA UZ GARĀS DWDM SISTĒMAS ENERGOEFEKTIVITĀTI}

D. Pavlovs, Vj. Bobrovs, M. Parfjonovs, A. Alševska, G̣. Ivanovs

Kopsavilkums

Šajā rakstā ir izpētīta DWDM sistēmu energoefektivitātes lieluma atkarība no izvēlēta pārraides frekvences plāna, kurš izveidots saskaņā ar ITU-T rekomendāciju G.694.1. Ir aprēķināti reǵenerācijas iecirkṇa garumi un spektrālās efektivitātes lielumi, izmantojot dažādus starpkanālu intervālus. Atsevišķi rakstā ir analizēta signālu reǵenerācijas procedūrai nepieciešamā jauda, kura ir grafiski attēlota kā attiecība pret sistēmas kopējo patērēto jaudu. Visi aprēķini tika izpildīti trim populārākajiem signālu modulācijas formātiem - NRZ-OOK, NRZ-DPSK un DPQPSK, ar $10 \mathrm{Gbps}, 40 \mathrm{Gbps}$ un $100 \mathrm{Gbps}$ pārraides ātrumiem attiecīgi, kuri bieži tiek izmantoti mūsdienīgās DWDM sistēmās. Rezultāti ir attēloti kā funkcijas no pārraidītās informācijas apjoma, kas padara tos piemērotām sistēmām ar atšḳirīgu pieejamu spektra platumu.

17.08.2017. 